\title{
ECONOMIC JUSTIFICATION FOR FLORICULTURE DEVELOPMENT IN SERBIA
}

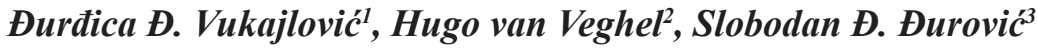

\begin{abstract}
Summary
Floriculture is a part of horticulture, an agricultural activity which has been on the rise during the past decades. It is different from traditional culture, not only due to the increased sales revenues, but also because flowers are ever more present in daily life, which has created opportunities for engaging in floriculture as a legitimate source of income. The aim of the paper is to present the current situation in the area offloriculture in the world and in Serbia, as well as to draw attention to the relationship between the import and export of floriculture products. This paper includes a SWOT analysis that provides an overview of the current state of floriculture in Serbia and the opportunities for its development. Floriculture is not widespread in Serbia, even though there are quite advantageous climatic conditions, fertile land, tradition and experience, but not enough innovation, inadequate equipment, technological lagging behind in production and insufficient harmonization with EU standards.
\end{abstract}

Key words: floriculture, ornamental plants, import, export, production

JEL: $Q 17, Q 13$

\section{Introduction}

Horticulture is the practice of plant growing in a relatively intensive manner, where people are engaged in the production process to a larger extent, contrary to agriculture which is largely based on the use of machinery in most of the countries in Western Europe. The basic principles of plant growing in the area of horticulture are based on (Adams, Bamford, Early, 2008): outdoor production, protected cropping, flower production

1 Đurđica Đ. Vukajlović Ph.D., Associate Professor, University Business Academy in Novi Sad, Faculty of Applied Management, Economics and Finance, Jevrejska Street no. 24, Belgrade, Serbia, Phone: +381 6073219 47, E-mail: vukajlovicdj@gmail.com.

2 Hugo van Veghel Ph.D., Assistant Professor, University Business Academy in Novi Sad, Faculty of Applied Management, Economics and Finance, Jevrejska Street no. 24, Belgrade, Serbia, Phone: +381 6052500 20, E-mail: h.vanvehgel@taraic.eu.

3 Slobodan Đ. Đurović, Ph.D. student, European University, Faculty of Business and Marketing, Belgrade, Serbia, Phone: +381 1133929 92, E-mail: slobodandjurovic@icloud.com.

EP 2017 (64) 2 (687-699) 
and garden construction, interior landscaping, turf culture, professional gardening and garden centres which sell plants and all gardening products. The horticulture industry is underdeveloped, so more needs to be done to promote it in relation to the plentiful economic, environmental and social benefits it provides to society. Horticulture can be defined as the science and art of growing fruits, vegetables, flowers and ornamental plants (Jaffee, 1995). A more general definition should, in addition to production and product (vegetables, fruits, ornamental plants) marketing, include relatively high values per product unit, high perishability with intensive utilization of land, labour knowledge, financial resources and other inputs, mainly in the production for a selected export market.

Many of the advantages of horticulture are not sufficiently recognized, so for most people flowers and other plants are only a part of their subconscious, something that is in the background and that has no significant role in everyday life. The horticulture industry is extremely complex and dynamic, and it represents a vital segment in the economies of a large number of countries and the global economy. As the countries all over the world become more urbanised, so will the importance of horticulture rise, because economic development results in people expecting a higher quality of life. On the other hand, horticulture is but one of many industries competing for scarce resources (land, water, energy, etc.), hence the utilization of those resources is evaluated in terms of its benefits and costs (Hall, Hodges, 2011).

Numerous studies have dealt with the economics of different aspects of floriculture (Khonphian, Pansila, Ritthidet, 2009; Adeniyi, 2015; Hussain, Khan, Jehanzeb, 2016) and they discussed the opportunities for the development of this economic area in a way that would enable the people engaged in this activity to make a good living for themselves. Floriculture is the latest addition to the commercial economic sector of agriculture and it is being developed in all of its potentials. Generally, the business of growing traditional flowers (typical for certain countries), as well as untraditional flowers and dried flowers is referred to as the floriculture industry, which encompasses the production, processing and marketing of all types of flowers (Kadam, 2012). In the context of floriculture, as a branch of agriculture, its difference from traditional husbandry is emphasized, not only due to the increased sales revenue, but because flowers are evermore present in daily life, which leads to opportunities for having floriculture as a source of income (Petar, 2008). Floriculture serves the purpose of raising income and reducing poverty in the developing countries. In certain labour-intensive economies which are not developed, the production of cut flowers is the main source of their comparative advantages (Labaste, 2005). That is further supported by the fact that the demand for flowers is increasing, both in the developed and in the developing countries, so the growing of different types of flowers has the capacity to enhance economic benefits, which include different aspects of floriculture, from production and sales to marketing (Manzoor et al, 2001). In order to develop the efficiency of the floriculture sector, the efficiency of the growers has to be enhanced, and to overcome the challenges they are facing, good management practices are necessary. Sustaining a 
successful business requires the production of high quality goods, which is the task of the growers, but the quality has to be distributed and the growers must take production costs into account in order to ensure the return of their investment, time and money. Flowers are viewed as a luxury product with high social value (Getu, 2009). The demand for these luxury products on the international market has increased during the past years. Most developing countries which have geographic advantages have included this activity as an opportunity to achieve faster economic growth (Frank, Cruz, 2001).

The ornamental plant industry has the potential to generate employment in urban and rural areas, directly or indirectly. That includes skilled employment categories such as nursery management, individual work on the growing and selling of plants. However, if the floriculture industry is compared with horticulture products, it can be concluded that the development of floriculture requires more investment, more growing technology and better management (Xia et al, 2006).

The production of floriculture is increasing by the average annual rate of 10 per cent, and approximately 50 countries are at present actively involved in the production of floriculture to a large extent. In addition to production, there has been an increase in the consumption of floriculture products in the developed and the developing countries (Hanafi, 2012). That lead to enhanced efforts at the world floriculture market causing the overall revenue to increase at the annual rate of 10 to 15 per cent (revenue is measured in billions of dollars).

Europe has traditionally been the largest exporter of floriculture in the world. The Netherlands, Italy, Germany, Spain, Great Britain and France are the main centres of production, while significant growth in production has recently been recorded in Poland (Van Huylenbroeck, 2010). Consumers purchase floriculture due to tradition, culture and their way of life. They demand products that are consistent in terms of quality, price and added value or that are priced lower. This dynamic industry continuously demands different types of products; it requires the knowledge of product origin and production techniques, and asks for different arrangements, which stresses the adaptability of all actors involved in this activity.

\section{State of floriculture in the European Union}

The world flower trade is characterised by a high level of concentration of products and their sources. Roses are the chief trading product, with Germany being the main import market and the Netherlands the world's leading exporter, as a country with highly developed and intensive agriculture in which the traditional sector of floriculture is of high importance. The reason why the Netherlands is the largest exporter of flowers in the world lies primarily in the fact that this country has the most efficient and the most innovative producers, in addition to having an efficient distribution system which is supported by good road and air networks.

A concern present in the production of floriculture is the issue of environmental protection (Simeunović, 2016), since the consumers have become apprehensive of the 
use of chemicals because plant preservation chemicals and fertilizers are intensively used in floriculture. In order to keep the production trends at the same level, or even to increase them, steps have been made to lower the use of chemicals, and in 2009 the Netherlands banned from use a number of pesticides in order to protect the environment. That helped the flower industry to improve its image and keep the growth trend going.

At the retail level, flowers are sold at a variety of places, including traditional flower shops, garden centres, supermarkets and street markets. The ways and the share of sales vary from country to country, although the share of supermarket sales is generally speaking on the rise.

The data on the production of flowers and ornamental plants in the EU has been provided in Graph 1. Countries were divided into the old members of the EU (Old Member State - OMS) and the new members who have accessed the EU since 2004 (New Member State - NMS). The graph shows that the production in the old member states is high above the production of the new member states and that there is a large discrepancy in production values between these two categories of states.

Graph 1. Production of flowers and ornamental plants in the EU (expressed in producer prices)

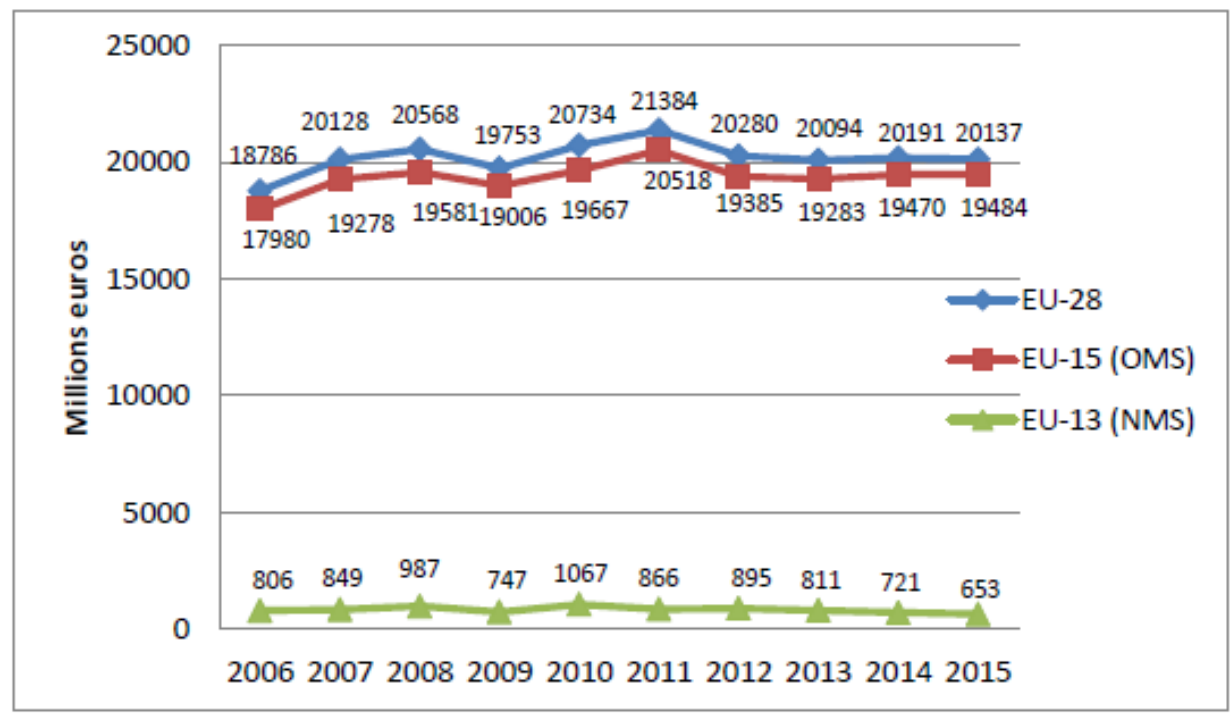

Source: European Commission (2016): Flowers and ornamental plants - Horticultural products, Statistics 2006-2015, Working document.

Table 1 provides the values of production per EU country, as well as the share percentages. It can be noted that the Netherlands. Italy, Germany, France and Spain have a joint share of $79.7 \%$ of the total value of flower and ornamental plant production. Moreover, it is apparent that there are a large number of countries (mainly the ones which joined the EU later) whose share is less than $1 \%$ which affirms the view that floriculture is a significant segment in the agricultural production of only a small number of countries. 
Table 1. Value of the production of flowers and ornamental plants per EU country

\begin{tabular}{|c|c|c|c|}
\hline States & Old/New member state & Prices in millions euro's & \begin{tabular}{|l} 
Share in 2015 \\
\end{tabular} \\
\hline Netherlands & OMS & 5376 & $28.5 \%$ \\
\hline Italy & OMS & 2533 & $13.4 \%$ \\
\hline Germany & OMS & 2756 & $14.6 \%$ \\
\hline France & OMS & 2456 & $13.0 \%$ \\
\hline Spain & OMS & 1932 & $10.2 \%$ \\
\hline United Kingdom & OMS & 968 & $5.1 \%$ \\
\hline Belgium & OMS & 773 & $4.1 \%$ \\
\hline Portugal & OMS & 400 & $2.1 \%$ \\
\hline Denmark & OMS & 402 & $2.1 \%$ \\
\hline Austria & OMS & 261 & $1.4 \%$ \\
\hline Sweden & OMS & 249 & $1.3 \%$ \\
\hline Romania & NMS & 92 & $0.5 \%$ \\
\hline Greece & OMS & 105 & $0.6 \%$ \\
\hline Hungary & NMS & 143 & $0.8 \%$ \\
\hline Finland & OMS & 103 & $0.5 \%$ \\
\hline Czech Republic & NMS & 59 & $0.3 \%$ \\
\hline Poland & NMS & 75 & $0.4 \%$ \\
\hline Slovenia & NMS & 27 & $0.1 \%$ \\
\hline Cyprus & NMS & 9 & $0.0 \%$ \\
\hline Lithuania & NMS & 14 & $0.1 \%$ \\
\hline Slovakia & NMS & 12 & $0.1 \%$ \\
\hline Latvia & NMS & 4 & $0.0 \%$ \\
\hline Estonia & NMS & 2 & $0.0 \%$ \\
\hline Luxembourg & OMS & 4 & $0.0 \%$ \\
\hline Bulgaria & NMS & 21 & $0.1 \%$ \\
\hline Malta & NMS & 0 & $0.0 \%$ \\
\hline Croatia & NMS & 93 & $0.5 \%$ \\
\hline Ireland & OMS & - & - \\
\hline UE-28 & & 18867 & $100.0 \%$ \\
\hline UE-15 (OMS) & & 18316 & $97.1 \%$ \\
\hline UE-13 (NMS) & & 550 & $2.9 \%$ \\
\hline
\end{tabular}

Source: European Commission (2016): Flowers and ornamental plants - Horticultural products, Statistics 2006-2015, Working document.

Graph 2 provides an overview of the use of land for the production of flowers and ornamental plants in the EU countries. It can be seen that the Netherlands had between 25,000 and 30,000 hectares of land under flowers and ornamental plants during the observed period, while no other observed country's land use exceeded 10,000 hectares. On that basis, we can conclude that the Netherlands is the dominant leader in the European Union when it comes to the land area used for floriculture products as well. 
Graph 2. Land use for flowers and ornamental plants in the European Union countries

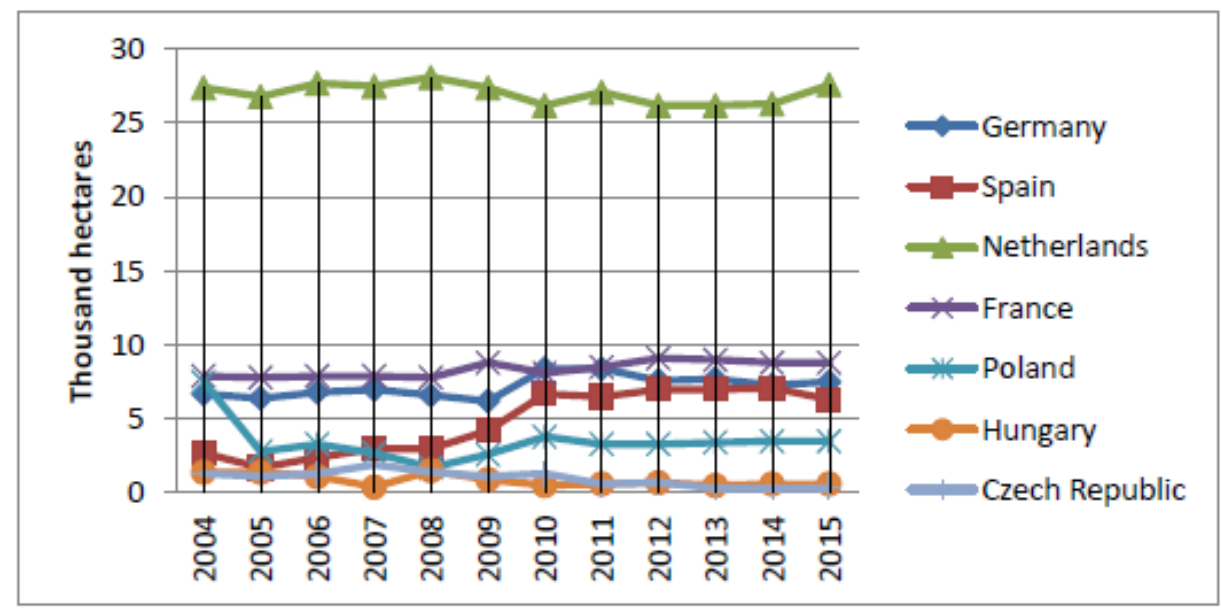

Source: European Commission (2016): Flowers and ornamental plants - Horticultural products, Statistics 2006-2015, Working document.

Graph 3 provides an analysis of trade in the four main categories of floriculture products: cut flowers (roses, carnations, orchids, gladiolas, chrysanthemums, etc.), potted plants, conifers and perennial plants, and bulbs and corms. The results indicate that the trade balance is overall positive, while being extremely negative for cut flowers. The most positive trade exchange balance is for bulbs and corms in all observed periods, except in 2013. It is apparent that the EU has a positive trade balance and that the trade of flowers and ornamental plants is a lucrative business.

Graph 4. Trade balance of floriculture products in the European Union (in thousands of EUR, Import-Export)

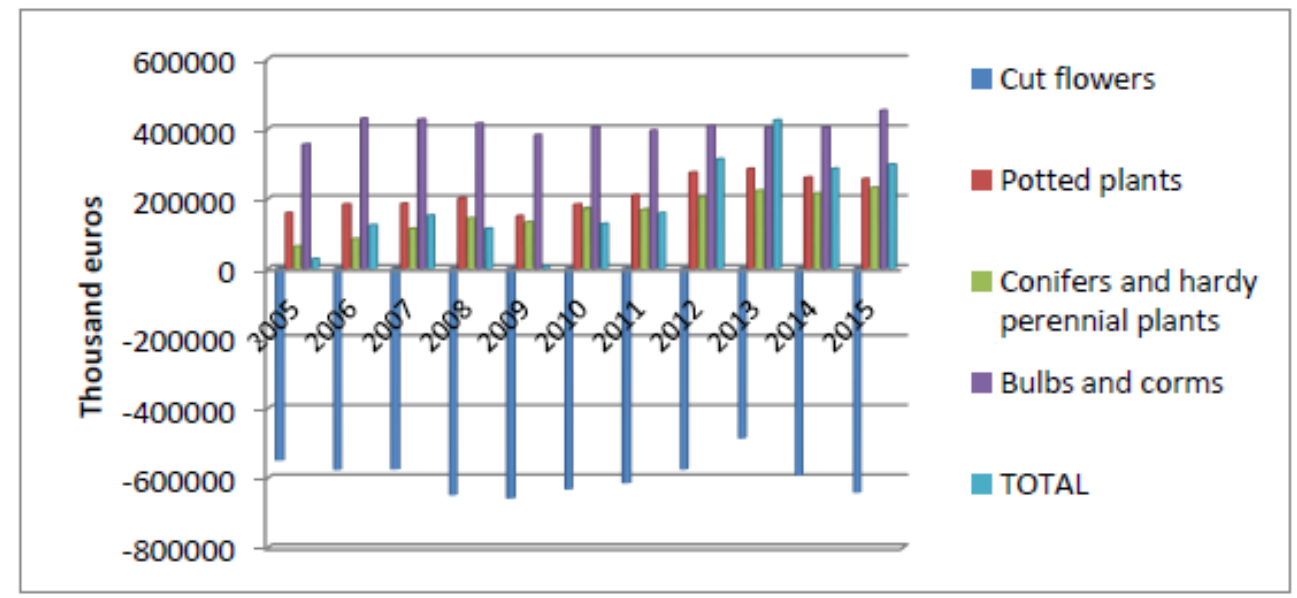

Source: European Commission (2016): Flowers and ornamental plants - Horticultural products, Statistics 2006-2015, Working document. 


\section{Floriculture in Serbia}

Serbia is distinguished by its plentiful land resources and a favourable climate, so agriculture represents a vital sector in the Serbian economy. Two thirds of the population in rural areas are engaged in agriculture. A plethora of favourable natural conditions result in quite diversified agricultural production.

The total area of Serbia amounts to 5,051,000 hectares, with arable land constituting $3,295,000$ hectares. Agricultural land takes up approximately $70 \%$ of the total area of Serbia, while $30 \%$ is under forests. $65.2 \%$ of the total agricultural area is covered by ploughlands and gardens, while pastures cover $16.5 \%$, meadows $12.4 \%$, orchards and vineyards $4.8 \%$, and $1.1 \%$ is classified as other In terms of the ownership structure, private producers have a share of $49.70 \%$ in the production of ornamental plants. Public enterprises that produce forest tree planting materials as a part of some nurseries' product lines also offer woody ornamentals. Public utility companies which take care of green spaces produce planting materials for seasonal flowers, perennials and woody plants for their own needs or to be sold on the local market (Glavendekić, 2013).

The data provided by the Statistical Office of the Republic of Serbia does not take floriculture into account. The closest to it is the data on nurseries as places where useful plants are grown. Even though the data on floriculture is not taken into account, the land area of flowers is listed, which is provided in Table 2. It can be seen that flowers do not even cover one per cent of the total land, but there was an increase in the land area of flowers in 2015.

Table 2. Land area of flowers in the Republic of Serbia

\begin{tabular}{|c|c|c|}
\hline \multicolumn{1}{|l|}{ YEAR } & $\begin{array}{c}\text { TOTAL LAND } \\
\text { AREA in ha }\end{array}$ & $\begin{array}{c}\text { TOTAL LAND AREA OF } \\
\text { FLOWERS in ha }\end{array}$ \\
\hline 2013 & $3,406,320$ & 412 \\
\hline 2014 & $3,506,830$ & 343 \\
\hline 2015 & $3,468,519$ & 445 \\
\hline
\end{tabular}

Source: Annual Statistical Bulletin (2016), Statistical Office of the Republic of Serbia, Belgrade.

According to the data of the Statistical Office, Serbia imports floriculture products mainly from the Netherlands and Italy, while it exports to Russia, Ukraine, Macedonia and Montenegro. Table 3 provides the flower import and export figures in Serbia for the period 2009-2013. The average export of flowers during this period amounted to 10,423 tons, with the average value of 9.8 million euros, while 7.532 tons of flowers were imported on average, with 12.1 million euros being the average value. If the chain index of the export trends is observed, it can be seen that there was in increase between 2009 and 2010 in the amount exported by $1.02 \%$, but the value decreased by $16.65 \%$. In 2011 the amount exported was lower than in 2010, but the value increased by $22.42 \%$. In 2012 the amount exported was higher by $15.06 \%$ than in 2011 , but the value was lower by $16.05 \%$, while the amount exported in 2013 was higher by as much as $148.52 \%$, while the value increase was not as high as it was only $31.99 \%$ greater. 
If we take a look at the import figures, we can see that the quantity increased in 2010 compared to 2009 by $8.9 \%$, while the increase in value was at $1.31 \%$. Import decreased in 2011 compared to 2010 by $28.45 \%$, and the value decreased as well by $17.46 \%$. The amount imported in 2012 decreased by $1.64 \%$ compared to 2011 , but the value increased by $11.94 \%$, while the amount imported in 2013 decreased by $0.66 \%$ compared to 2012 while the value increased by $2.39 \%$.

By observing the discrepancies between imports and exports, we can see that export was lower than import in 2009 in terms of amounts and values, and the same is true of 2010 as well. In 2011, 2012 and 2013 there was a positive balance of imports and exports in terms of amounts, but not in terms of values, so it can be concluded that imports are still greater in value, as observed in the aforementioned period.

Table 3. Flower import and export trends observed in amounts and values

\begin{tabular}{|c|c|c|c|c|c|c|}
\hline & \multicolumn{2}{|c|}{ EXPORT } & \multicolumn{2}{|c|}{ IMPORT } & \multirow{2}{*}{$\begin{array}{l}\text { Amount } \\
\text { EXPORT- } \\
\text { IMPORT }\end{array}$} & \multirow{2}{*}{$\begin{array}{c}\text { Value } \\
\text { EXPORT- } \\
\text { IMPORT }\end{array}$} \\
\hline & $\begin{array}{c}\text { Amount } \\
(\mathrm{kg})\end{array}$ & Value (Eur) & $\underset{(\mathrm{kg})}{\text { Amount }}$ & Value (Eur) & & \\
\hline 2009 & $7,806,251$ & $10,154,436$ & $8,564,448$ & $12,840,802$ & $-758,197$ & $-2,686,366$ \\
\hline 2010 & $7,957,200$ & $8,462,996$ & $9,326,913$ & $13,009,501$ & $-1,929,713$ & $-4,546,505$ \\
\hline $\begin{array}{l}\text { Trends } \\
\text { in } 2010 \\
\text { compared to } \\
2009\end{array}$ & $1.02 \%$ & $-16.65 \%$ & $8.90 \%$ & $1.31 \%$ & - & - \\
\hline $\begin{array}{l}\text { Trends in } 2011 \\
\text { compared to } \\
2010\end{array}$ & $-8.81 \%$ & $22.42 \%$ & $-28.45 \%$ & $-17.46 \%$ & - & - \\
\hline 2011 & $7,256,040$ & $10,360,892$ & $6,673,222$ & $10,736,828$ & 582,818 & $-375,999$ \\
\hline $\begin{array}{l}\text { Trends } \\
\text { in } 2012 \\
\text { compared to } \\
2011\end{array}$ & $15.05 \%$ & $-16.05 \%$ & $-1.64 \%$ & $11.94 \%$ & - & - \\
\hline 2012 & $8,348,222$ & $8,697,901$ & $6,563,585$ & $11,681,365$ & $9,004,807$ & $-2,983,464$ \\
\hline $\begin{array}{l}\text { Trends } \\
\text { in } 2013 \\
\text { compared to } \\
2012\end{array}$ & $148.52 \%$ & $31.99 \%$ & $-0.66 \%$ & $2.39 \%$ & - & - \\
\hline 2013 & $20,747,093$ & $11,480,817$ & $6,529,854$ & $11,960,927$ & $14,217,239$ & $-480,110$ \\
\hline
\end{tabular}

Source: Statistical Office of the Republic of Serbia (2014): Fruit and Vegetables, Floriculture and Olive Oil, Agriculture and Rural Development; authors' estimate.

There are no quality standards for flowers in Serbia. Standards for woody ornamentals 
were designed in accordance with the European Nurserystock Association (ENA), but they are yet to be adopted. With concurrence by international organizations, these standards will be implemented on a voluntary basis since they are not mandatory according to the new regulation of the EU No. 1308/2013 on quality standards in the areas of flowers and ornamental plants.

In order to facilitate production, subsidies have been secured. The basic subsidy for plant production amounts to the minimum payment of $52 \mathrm{EUR} / \mathrm{ha}$, up to 100 ha of covered land area. Subsidies have been provided for fuel and fertilizers as well, while the subsidised insurance premium for plants, fruits, perennials, nursery stock and animals is at $40 \%$ of the paid insurance premium.

In terms of product range, seasonal and potted flowers are the most prevalent in Serbia, while the production of cut flowers is low. The value of export was at 1.7 million dollars, while the value of import was at 8.7 million dollars (Vujošević et al, 2007). During the past years production has grown at the annual rate of $20-30 \%$. That is a tremendously high growth rate, but it is nevertheless insufficient. There is great interest for cooperation from the Netherlands, Hungary and Germany, but the issue is that only 800,000 roses can be acquired from Serbia, while Poland, for example, offers 4.5 million. Experts from the Netherlands, the world's leader in flower production, state that the highest quality roses are grown at the south of France, that Serbia has the highest prices in the entire European market, while they describe the market of Great Britain as the pickiest.

After taking a look at the SWOT analysis (Image 1) of the production of flowers in Serbia, it can be deduced that the country has favourable natural predispositions for the development of floriculture, as well as a good geographic position. It has tradition and experience, accumulated knowledge and skills. However, it is technically and technologically lagging behind the developed countries, it does not have sufficient equipment and financial resources. Moreover, it does not have an adequate development strategy and the infrastructure is poor. Still, its chances lie in its open borders with the $\mathrm{EU}$, in increasing the synergistic effects through clustering and enhancing value creation through knowledge bases. Threats stem from the lack of investment, technological lagging behind, large number of imported products, as well as from the deficiency in good managers and discord with the EU standards. 
Image 1. SWOT analysis of floriculture in Serbia

\begin{tabular}{|c|c|}
\hline STRENGTHS: & WEAKNESSES: \\
\hline $\begin{array}{l}\text { Excellent land } \\
\text { Very good climate } \\
\text { Good geographic position } \\
\text { Low labour costs } \\
\text { There are schools and faculties which } \\
\text { offer horticulture courses } \\
\text { Tradition and experience } \\
\text { Entrepreneurship with growth potential } \\
\text { Good geographic/transport position } \\
\text { Accumulated knowledge and skills } \\
\text { Processing industry } \\
\text { Developed production networks }\end{array}$ & $\begin{array}{l}\text { Natural material resources are used } \\
\text { Technical/technological lagging behind } \\
\text { Insufficient equipment } \\
\text { Insolvent financial resources } \\
\text { Lack of a development strategy } \\
\text { Difficulties in cooperation with others } \\
\text { Bad infrastructure for producers } \\
\text { (irrigation) } \\
\text { High import taxes and fees }\end{array}$ \\
\hline OPPORTUNITIES: & THREATS: \\
\hline $\begin{array}{l}\text { Resource optimization - increase of } \\
\text { value per unit of invested raw materials } \\
\text { Enhancement of value creation (through } \\
\text { knowledge bases, communication) } \\
\text { Facilitation of synergistic effects } \\
\text { (through clustering) } \\
\text { Joint marketing (joint appearances at } \\
\text { fairs, image strengthening) } \\
\text { Open borders with the EU countries } \\
\text { Development of fresh flower sales at the } \\
\text { Balkan market }\end{array}$ & $\begin{array}{l}\text { Long-term lack of investment } \\
\text { Technological lagging behind } \\
\text { Emergence of imported products at the } \\
\text { domestic market } \\
\text { Market problems caused by economic } \\
\text { instability } \\
\text { Deficiency of good managers with } \\
\text { practical experience } \\
\text { Discord with the EU standards }\end{array}$ \\
\hline
\end{tabular}

Source: Author

\section{Conclusion}

Production of ornamental plants represents a valuable potential in agricultural production, landscape architecture and other service activities, and Serbia has favourable climate conditions, geothermal resources and expert labour force. However, the value of imported floriculture products in Serbia is greater than the value of the exports.

The international horticulture market as growing, but it is highly competitive as well. A large portion of Serbian horticulture is still very limited and mainly owned by small estates, while the support infrastructure is underdeveloped. The development of floriculture cannot be based on tradition; investments into advanced production have to be made.

Growing of flowers should be treated as an independent economic activity with the introduction and utilization of EU recommendations and regulations. It is necessary to include the Eurostat codes for floriculture products in the list of national codes on 
flowers, as well as to introduce appropriate $\mathrm{CN}$ in customs procedures ${ }^{4}$. It is essential to stimulate the formation of relevant clusters in order to facilitate the transfer of knowledge and technology through networking and organization of B2B and B2C events. Opportunities in local and regional tourism should be utilized through flower festivals, by the introduction of flowers as well as a wide array of derivative products (food items, old crafts, souvenirs, etc.). Subsidies should stimulate the production of floriculture products in order to support this activity and enhance the competitiveness of local producers on the foreign market.

\section{Literature}

1. Adams, C.R., Bamford, K.M., Early, M.P. (2008): Principles of horticultre, Elsever Ltd., Oxford, London.

2. Adeniyi, S. A. (2015): Contribuition of some ornamental plants to the socioeconomic development of urban household in Akure metropolis, African Journal of Agricultural Research, Vol. 10, No. 4, pp. 264-268.

3. European Commission (2016): Flowers and ornamental plants - Horticultural products, Statistics 2006-2015, Working document, (available at: https://ec.europa. eu/agriculture/sites/agriculture/files/fruit-and-vegetables/product-reports/flowers/ statistics-2016 en.pdf)

4. Frank, B., Cruz, E. (2001): Flower for Justice, Implementing the International Code of Conduct, Friedrch Ebert Stiftung.

5. Getu, M. (2009): Ethiopian Floriculture and its Impact on the Enviroment, Mizan Law Rev., Vol. 3, No. 2, pp. 240-270.

6. Glavendekić, M. (2013): Proizvodnja i promet ukrasnih biljaka u Srbiji, Biljni lekar, Vol. 41, No. 6, pp. 605-610.

7. Hall, C.R., Hodges, W.A. (2011): Economic, Environmental and Well-Being Benefits of Lifestyle Horticulture, Chronica Holticulture, Vol. 51, No. 4, pp. 5-8.

8. Hanafi, Y. S, (2012): Ecology and Agriculture in the Himalayan Region, Concept Publishing Company Pvt. Ltd., New Delhi, India.

9. Hussain, A., Khan, A., Jehanzeb (2015): The marketing and cost-benefit analysis of floriculture in the rural areas of Peshawar: A case study of Bazid Khel, City University Research Jorunal, Vol. 5. No. 1, pp. 49-63.

10. Jaffee, S. (1995): Marketing Africa's High-Value Foods: Comparative Experiences of an Emergent Private Sector, Kendall/Hunt Publishing company, Dubuque (Iowa).

11. Kadam, P.H. (2012): An Economic study offloriculture in Pune, Synopsis submitted to Tilak Maharashtra Vidyapeeth, Pune for the degree of doctor of philosophy $[\mathrm{PhD}]$ in economics under the guidance of Dr. Praveen Jhadav, HoD of Sector, The World Bank.Economics (available at: http://shodhganga.inflibnet.ac.in/

4 http://ec.europa.eu/taxation_customs/customs/customs_duties/tariff_aspects/combined nomenclature/index en.htm

EP 2017 (64) 2 (687-699) 
bitstream/10603/5658/16/16_synopsis.pdf)

12. Khonphian, K., Pansila, W., Ritthidet, P. (2009): Developing Ornamental Plants for Promoting Community Economy, Jorunal of Social Science, Vol. 5, No. 4, pp. 314318.

13. Labaste, P. (2005): The European horticulture market: Opportunities for SubSaharan African Exporters, Working Paper No. 63, The World Bank, Washington.

14. Manzoor, R., Shahid, S.A., Baluch, M. (2001): Economics offloriculture in Pakistan: A case study of Lahore market, Pakistan Economic and Social Review, Vol. 39, No. 2, pp. 87-102.

15. Peter, K.V. (2010): Flowers for Trade, Horticulture Science Series-10, New India Publishing Agency, New Delhi.

16. Republički zavod za statistiku (2014): Fruit and vagetables, floriculture and olive oil, Agriculture and rural Development (available at: http://www.eu-pregovori.rs/ files/File/documents/skrining/bilateralni/prezentacije/pg11/pg11_26.pdf)

17. Simeunović, T. (2016): Menadžerski aspekti međuzavisnosti zaštite životne sredine i budžeta, Oditor, Vol. 2, No. 1, pp. 25-29.

18. Statistički godišnjak (2016), Republiki zavod za statistiku, Beograd, (available at: http://pod2.stat.gov.rs/ObjavljenePublikacije/G2016/pdf/G20162019.pdf)

19. Taxation and custom union - The combined nomenclature (available at: http:// ec.europa.eu/taxation customs/customs/customs duties/tariff aspects/combined nomenclature/index en.htm)

20. Van Huylenbroeck, J. (2010): Status offloriculture in Europe, Protocols for In Vitro Propagation of Ornamental Plants. editors: Mohan, S. J., Ochatt, S. J., Humana Press, p. 365-376.

21. Vujošević, A., Lakić, N., Beatović, D., Jelačić, S. (2007): Influence of slow disintegrating fertilizer rates on quality of Gazania seedlings, Journal of Agricultural Sciences Vol. 52, No. 2, pp. 121-130 


\title{
EKONOMSKA OPRAVDANOST RAZVOJA FLORIKULTURE U SRBIJI
}

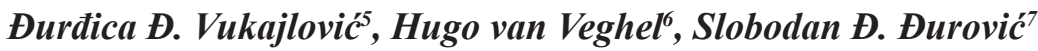

\begin{abstract}
Sažetak
Florikultura predstavlja deo holtikulture, poljoprivredne delatnosti koja je poslednjih decenija sve više u ekpsnziji. Različita je od tradicionalne kulture, ne samo zbog povećanja prihoda od prodaje, već i zato što je cveće sve više prisutno u svkodnevnom životu, što je $i$ dovelo do mogućnosti bavljenja florikulturom kao izvorom sredstava za život. Cilj rada je da se predstavi trenutna situacija u oblasti florikulture u svetu $i$ u Srbiji, kao i da se ukaže na odnos uvoza i izvoza proizvoda florikulture. U radu je predstavljena SWOT analiza kojom je data slika trenutnog stanja florikulture u Srbiji $i$ mogućnosti razvoja. Florikultura u Srbiji nije dovoljno zastupljena, iako postoje veoma dobri klimatski uslovi, plodno zemljište, tradicija i iskustvo, ali nedovoljno inovranja, nedovoljno opreme, tehnička zastarelost u proizvodnji i nedovoljna usklađenost sa standardima EU.
\end{abstract}

Ključne reči: florikultura, ukrasno bilje, uvoz, izvoz, proizvodnja

5 Vanredni profesor, dr Đurđica Đ. Vukajlović, Univerzitet Privredna akademija u Novom Sadu, Fakultet za primenjeni menadžment, ekonomiju i finansije, Jevrejska ulica br. 24, Beograd, Srbija, Telefon: +381 6073219 47, E-mail: vukajlovicdj@gmail.com.

6 Docent, dr Hugo van Veghel, Univerzitet Privredna akademija u Novom Sadu, Fakultet za primenjeni menadžment, ekonomiju i fiansije, Jevrejska ulica br. 24, Beograd, Srbija, Telefon: +381 6052500 20, E-mail: h.vanvehgel@,taraic.eu.

7 Slobodan Đ. Đurović, Master, Student doktorskih studija, Evropski Univerzitet, Fakultet za biznis i marketing, Beograd, Srbija, Telefon: +381 1133929 92, E-mail: slobodandjurovic@icloud.com.

EP 2017 (64) 2 (687-699) 